\title{
Mental Health and Psychosocial Care for People with Disabilities
}

\author{
José Ricardo de Abreu Afonso ${ }^{1 *}$; Adrielly Kayane da Silva Sena ${ }^{1}$; Cátia Maria Silva de Oliveira ${ }^{1}$ \\ 1 Department of Psychology, Center for Humanities, University Center of Vitória de Santo Antão (UNIVISA), Vitória de Santo Antão, Brazil \\ E-mail adresse: adriellysenasz@gmail.com (Adrielly Kayane da Silva Sena); catyasilvaoliveira@hotmail.com (Cátia Maria Silva de Oliveira); \\ ricardoabreu1980@gmail.com (José Ricardo de Abreu Afonso); \\ ${ }^{*}$ Corresponding author
}

\section{To cite this article:}

Sena, A.K.S.; Oliveira, C.M.S; Afonso, J.R.A. Mental Health and Psychosocial Care for People with Disabilities. International Journal of Sciences. Vol. 1, No. 1, 2021, pp. 15-19.

Received: 01 28, 2021; Accepted: 02 01, 2021; Published: 02 02, 2021

\begin{abstract}
Much is discussed about the importance of having good mental health, especially in this pandemic time of the new Coronavirus that we are facing. Some psychologists claim that mental disorders arising from this context will last for a longer time than the virus itself, showing the great impact on mental health of almost half of the world's population. When we talk about mental health and psychosocial care to people with disabilities, we find a very scarce literature, sometimes only mentioning a certain type of disability, when in fact if there is a need to have a macro, critical and sensitive look on the subject, taking into account all types of disability, whether of hereditary, congenital or acquired origin.
\end{abstract}

Keywords: Mental Health; Psychosocial Care; Disabled Person (PCD); Discrimination; Prejudice; SPSS.

\section{Introduction}

The Statute of persons with disabilities (2015), in Chapter III, Article 18, paragraph V, ensures psychological care for both persons with disabilities (PCD), as well as for their relatives and personal attendants. Inspired by this article of the Statute, a research was elaborated by students of the 2nd period of the Psychology Course of UNIVISA. According to data issued by the World Health Organization (WHO) (2011), it is estimated that about one billion people worldwide have some kind of disability. These types can be classified as hereditary, congenital and acquired deficiency. It is estimated that $23.9 \%$ of the Brazilian population, about 45.6 million people, according to the census conducted in 2010 by the Brazilian Institute of Geography and Statistics (IBGE), have some type of disability, be it sensory, mental, physical or intellectual factor. The aim of this study is to provoke the reader to reflect, discuss and awaken a critical sense about the guarantee and legitimacy of PCD rights, immediate access to psychosocial care and the fight against capacitive and Social Darwinism. In view of what was previously exposed, it is important to present the definitions and main differences between the three types of disability, based on the texts of Souza and Carneiro (2007).

The deficiency transmitted by the parents to their descendants, that is, of genetic cause, is called hereditary and may manifest late or not. It is important to emphasize that the disability will occur, as the authors attest, regardless of whether or not the mother has all the assistance and follow- up of the health service throughout her gestational period. Congenital deficiency is the one that is generated with the individual and can come from several factors, including: alcohol use, illicit drugs, some medications during pregnancy, infectious infectious diseases transmitted to the fetus and that generate sequelae (such as syphilis, rubella and measles), precariousness or failures in the primary health care service, making it impossible for pregnant women to follow up prenatal care or do so incompletely, where manifestations of disability could be avoided or at least mitigated if treated early through quality gestational follow-up.

The acquired deficiency comes from sequelae resulting from accidents, such as at work, in domestic accidents, in traffic, in the handling of firearms and sharp objects, with fireworks and others, causing serious injuries. It is also important to remember that diseases can leave permanent sequelae in the individual such as cancer, ophthalmologic diseases such as glaucoma and diabetes.

On the acceptance of disability when acquired, Resende and Neri (2009) comment that this event in the individual's life, even as a young person, tends to be accepted more easily, perhaps because young people are usually more tender in their acts before life and more willing to allow themselves to experience new means or mechanisms that help to perform activities. Goffman (1982) talks about the stigmatization of the person with a higher age, which allows one to see itself as "deficient", based on the reports of other people who suffer stigmas and who acquired a disability before him.

According to Francelin, Motti and Morita (2010), 
adaptation to disability becomes more difficult for adults when it is acquired, because this significantly implies the compromise of their economic situation. The individual tends to move away from his/her labor activities for a while and sometimes definitively, depending on the degree of the problem acquired. It is possible that the individual will have difficulty finding a new job and will depend only on the financial help of family members or aid given by the government for their survival. On the other hand, there is a feeling of loss of social security, because the PCD begins to live sometimes with discrimination and prejudice, not only by society but also by family members, and may also undergo relevant changes in their relationships, provoke selfrejection and experience stressful situations. These studies that demonstrate the psychosocial consequences pointed out by the authors refer to people who have somehow acquired hearing loss, but this also allows us to use the same concepts and observations and apply them or fit them into other types of disability.

With regard to accessibility to education, Nilton Cunha (2013), in his book "Higher education and inclusive education: the right to equality and difference", a work resulting from his work with inclusive education for PCD in schools of the state public network in the metropolitan region of Recife, proposes to discuss a democratic and participatory education, which promotes change in the way people with disabilities are seen, as a capable person and a transformative agent like anyone else. It also points to the architectural structures of educational institutions, especially universities, aiming at better accessibility. It encourages the installation of handrails, access ramps for wheelchair users, elevators, doors with braille registration, expanded information for people who have visual limitation, adaptable bathrooms, training of interpreters for the deaf and technical help of assertive technologies, promoting the individual autonomy throughout the learning and teaching process. This is an important step in terms of inclusion that certainly helps the individual to maintain good mental health and enables a sense of well-being and acceptance.

Oliveira (2000), comments that an acquired physical disability can act as a determining agent and be an impacting factor in the individual's history, taking into account the way these subject deals with experience. This differs evidently from person to person, as we have to consider their life history, their social security and personality in the face of prejudice to their physical disability. It is possible to observe that, while some cannot accept their condition, punishing themselves and acquiring severe mental disorders, others manage to resignify their difficulties and develop skills and practices never explored until then. They end up becoming people with more desire to live, more tolerant in the face of adversities and who value the simple things in life. The difficulty in modeling their current condition is noticeable in subjects in adulthood, where acceptance of acquired disability is more difficult, because it requires new adaptations to the situation they are experiencing, because they already have predefined behaviors, requiring greater effort to make adjustments to new experiences, as attested by Murta and Guimaraes (2007).

\section{Methodology}

Based on a quantitative search, the research data were obtained using Google Forms as a tool to collect them, containing 21 closed questions in this form. A link was sent randomly by all members of the survey through a message application so that everyone could access and respond to the polls, thus respecting the isolation and social distancing that the current situation requires, due to the covid-19 pandemic. After the collection of the answers, the data were inserted in the software Statistical Package for the Social Sciences (SPSS) Version 2.0, so that the results commented below were generated, giving scientific basis and promoting a descriptive statistical research with percentage values. Bibliographic research was also carried out by academic authors, allowing the observation of different points of view on the same theme and contributing in a relevant way to exemplify the data obtained enabling a close link between the information collected in the research with the authors' reflections.

\section{Results and Discussion}

In all, 27 people responded to the form. We observed through the data collected in the research, a very balanced number in relation to the type of disability that the respondents have; 14 people $(51.9 \%)$ reported having congenital disability, while 13 people $(48.1 \%)$ answered that their disability is acquired. We ask the research participants to provide the "degree of mental health" based on their life habits through the perception that each one has about themselves. To measure this degree of quality, a scheme was elaborated where each participant would give a score that would correspond to his/her vision with regard to his/her mental health, distributed as follows: 0 for poor; 1 for bad; 2 for good and 3 for great. We observed that $22.2 \%$ of the surveyed answered that their mental health is poor. On the other hand, $51.9 \%$ answered that they were good and $25.9 \%$ said they were excellent.

Regarding their interpersonal relationships, 92.6\% answered that they were single, which may be associated with a possible difficulty in finding a partner and $33.3 \%$ said they had difficulties in accepting their condition as PCD. $63 \%$ of those surveyed said they had suffered prejudice and discrimination at some point in their lives. Data collected in our research revealed that the level of education of $37 \%$ of those who were "interviewed" had complete higher education, which draws attention, as it represents the majority of respondents. Despite these figures, we know that the road is still long for an equal education. Tables 1, 2 and Figure 1 are the statistical samples described in percentage and the graph helps in the analyses of the issues addressed in the research for a better understanding, exemplifying and use of real data. 
Table 1. If you could measure the quality of mental health based on your lifestyle habits, what grade would you give, being 0 for (bad), 1 (bad), 2 (good) and 3 (excellent)?

\begin{tabular}{|c|c|c|c|c|c|c|c|c|}
\hline & \multirow{3}{*}{ Frequency } & \multirow{3}{*}{ Percentage } & \multirow{3}{*}{$\begin{array}{c}\text { Percentage } \\
\text { Valid }\end{array}$} & \multirow{3}{*}{$\begin{array}{l}\text { Cumulative } \\
\text { Percentage }\end{array}$} & \multicolumn{4}{|c|}{ Autoinitialization for Percentage } \\
\hline & & & & & \multirow{2}{*}{ Bias } & Standard & \multicolumn{2}{|c|}{$95 \%$ C.I. } \\
\hline & & & & & & Error & Lower & Superior \\
\hline Bad & 6 & 22,2 & 22,2 & 22,2 & $-1,4$ & 7,3 & 7,4 & 34,9 \\
\hline Good & 14 & 51,9 & 51,9 & 74,1 &,- 5 & 10,2 & 31,7 & 72,0 \\
\hline Excellent & 7 & 25,9 & 25,9 & 100,0 & 1,9 & 8,7 & 13,2 & 46,0 \\
\hline Total & 27 & 100,0 & 100,0 & & , 0 & ,0 & 100,0 & 100,0 \\
\hline
\end{tabular}

a. Unless otherwise stated, the autoboot results are based on 100 bootstrap samples

\begin{tabular}{|c|c|c|c|c|c|c|c|c|}
\hline as a $\mathrm{PCD}$ ? & & & & & & & & \\
\hline & \multirow{3}{*}{ Frequency } & \multirow{3}{*}{ Percentage } & \multirow{3}{*}{$\begin{array}{c}\text { Percentage } \\
\text { Valid }\end{array}$} & \multirow{3}{*}{$\begin{array}{l}\text { Cumulative } \\
\text { Percentage }\end{array}$} & \multicolumn{4}{|c|}{ Autoinitialization for Percentage } \\
\hline & & & & & \multirow{2}{*}{\multicolumn{2}{|c|}{$\begin{array}{l}\text { Standard } \\
\text { Error }\end{array}$}} & \multicolumn{2}{|c|}{$95 \%$ C.I. } \\
\hline & & & & & & & Lower & Superior \\
\hline $\mathrm{Bad}$ & 9 & 33,3 & 33,3 & 33,3 & $-1,6$ & 9,0 & 14,8 & 51,9 \\
\hline Good & 16 & 59,3 & 59,3 & 92,6 & 1,0 & 9,9 & 42,8 & 83,1 \\
\hline Excellent & 2 & 7,4 & 7,4 & 100,0 & ,6 & 5,0 &, 0 & 20,1 \\
\hline Total & 27 & 100,0 & 100,0 & &, 0 & 0 & 100,0 & 100,0 \\
\hline
\end{tabular}

a. Unless otherwise stated, the autoboot results are based on 100 bootstrap samples

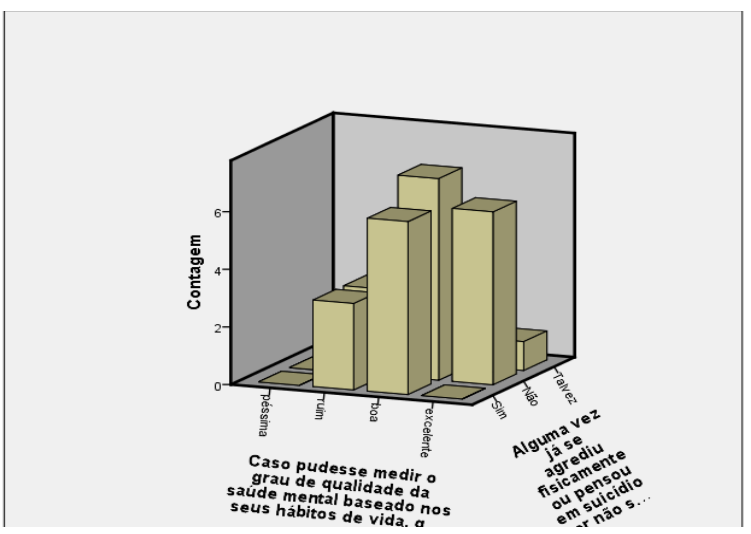

Figure 1. 3D bar graph assembled through the SPSS Version 2.0 program, allowing to make a relationship between the quality of the life habits of the Disabled Person, with his mental health.

When asked about suicide, $33.3 \%$ said they had thought about it, $59.3 \%$ answered that no and $7.4 \%$ said that perhaps, that is, the majority answered categorically that they did not, and this may be associated with the fact that they have more accessibility to information, to contents that allow a more solid and more enlightened intellectual formation and formation. Possibly, a reinforcing data for this thought is the fact that the majority had attended or were attending higher education $(37 \%)$, while $22.2 \%$ claimed to have incomplete higher education. Those of complete high school, on the other hand, correspond to $25.9 \%$. Those with elementary education, both complete and incomplete, $3.7 \%$. This is not to say that those with a higher educational level are better than others or are not likely to commit against themselves some kind of harm that will cost their lives, but access to an inclusive education can result in a more thoughtful, balanced mind and willing to face with emotional intelligence the reverses of life, the prejudiced gestures and opinions on the part of society, without losing its dignity and its reference to the human person.

Although the form sent to the survey was quite discreet, not containing the option of identifying the surveyed, either by name, e-mail or telephone, some of the participants who received the link and answered the questions, expressed gratitude and praised the initiative as: "noble attitude", "I really liked to participate", "thank you for remembering us, because we are the invisible ones of society".

This agenda should be in everyone's interest, taking into account that any individual may one day become a disabled person, for variable causes. About $77.8 \%$ of those involved in the research said they missed a debate focused on mental health and psychosocial care of PCD. For $92.6 \%$ the support of family and friends, forming a support network, is fundamental for their mental well-being. Thinking and rethinking in the best possible way in the planning of our cities is important, for example, in an infrastructure that allows residents with disabilities to have more urban mobility, in autonomous access to public buildings, financial institutions, living spaces and others. Promoting basic conditions of accessibility, social inclusion, with equal opportunities to the labor market and essential health and transportation services, helps to rescue the individual's self-esteem, through the psychosocial care received and the guarantee of their rights, as governed by the Statute of the Person with Disabilities.

\section{Conclusions}

Putting one another's place, respecting differences, welcoming and being sympathetic to those who, in some way, at a certain moment in their lives, have had their destinies modified by a disability, whatever their nature, makes us understand our own weaknesses and limitations. Undressing us in armor that we think is impenetrable or unfailing. Society needs to free itself from certain issues, including prejudice and intolerance to the different, in the way we treat people with disabilities. To try to exemplify, simply, just remember that the term used for the person who receives the Benefit of Continuous Benefit (BPC), which is within the LOAS (Organic Law of Social Assistance), is that of social support for disability. We can understand that the individual has difficulties in performing labor activities, paid, but this does not necessarily mean that this person is invalid, quite the contrary. This individual has a history, an identity, that must be respected and preserved. We need to review certain "concepts" that stigmatize, disaggregate and further foster prejudice and discrimination against people who face the challenges arising from their disability on a daily basis. We hope that this work can contribute positively to a discussion based on empathy, otherness and respect for different opinions and the disuse of capacitive thinking. 


\section{References}

[1] CUNHA, Nilton Pereira da, 1996- O ensino superior e a educação inclusiva: o direito à igualdade e à diferença / Nilton Pereira da Cunha; prefácio Manuel Tavares. - Recife: Ed. do Autor,2013. 258p.

[2] Estatuto da pessoa com deficiência - Brasília: Senado Federal, Coordenação de Edições Técnicas, 2015. 65 p. Conteúdo: Lei no $13.146 / 2015$

[3] Francelin, M. A. S., Motti, T. F. G., \& Morita, I. (2010). As implicações sociais da deficiência auditiva adquirida em adultos. Saúde e Sociedade, 19(1), 180192.https://doi.org/10.1590/S0104-

$12902010000100015 \mathrm{https} / / /$ doi.org/10.1590/S010412902010000100015.

[4] Goffman, E. (1982). Estigma: Notas sobre a manipulação da identidade deteriorada (4a ed.). Rio de Janeiro,RJ: Zahar.

[5] Instituto Brasileiro de Geografia e Estatística - IBGE. (2012). Censo demográfico 2010: Características gerais da população, religião e pessoas com deficiência. Rio de Janeiro, RJ: o autor.

[6] Murta, S. G., \& Guimarães, S. S. (2007). Enfrentamento à lesão medular traumática. Estudos de Psicologia,12(1), 5763.https://doi.org/10.1590/S1413-

294X2007000100007https://doi.org/10.1590/S1413294X2007000100007.

[7] Oliveira, R. A. (2000). Elementos psicoterapêuticos na reabilitação dos sujeitos com incapacidades físicas adquiridas. Análise Psicológica, 18(4), 437-453.

[8] Organização Mundial de Saúde - OMS. (2011). World reportondisability. Malta: o autor.

[9] Resende, M. C., \& Neri, A. L. (2009). Ajustamento psicológico e perspectiva de velhice pessoal em adultos com deficiência física. Psicologia em Estudo, 14(4), 767776.https://doi.org/10.1590/S1413-

73722009000400017https://doi.org/10.1590/S141373722009000400017 .

[10] Souza, J. M., \& Carneiro, R. (2007). Universalismo e focalização na política de atenção à pessoa com deficiência. Saúde e Sociedade, 16(3), 69-84. https://doi.org/10.1590/S0104-12902007000300007.

[11] Santos, J. C e Carvalho-Freitas, M.N (2019). Processos psicossociais da aquisição de uma deficiência. Psicologia: Ciência e Profissão,39, 1-16. https://doi.org/10.1590/19823703003175434 